\title{
The Code Of Literature Of Acehnese Oral Literature In Jugi Tapa Saga
}

\author{
Yulsafli ${ }^{1}$; Burhanuddin $\mathrm{AG}^{2}$; Ismawirna ${ }^{3}$ \\ \{yulsafli@gmail.com\} \\ ${ }^{1,2,3}$ Serambi Mekkah University of Banda Aceh, Indonesia
}

\begin{abstract}
Jugi Tapa saga is oral literature in Sawang District. North Aceh Regency, Aceh Province. This saga tells the story of the main character named Leubee Muda. Then, Leubee Muda became a heretic because he opposed his teacher named Teungku Lhok Drien. After his heresy, he was called Jugi Tapa, who became the title of this saga. One day, his teacher asked him to deliver a book to Teungku Jambo Haji. The teacher advised him not to read the book. However, Leubee Muda violated the mandate of his teacher, he read and practiced the entire contents of the book. Because of his intelligence, in a short time, he can master all the knowledge contained in the book. To perfect his magic, he must meditate and marry one hundred beautiful women, some of whom are king's wives and daughters of dignitaries. Jugi Tapa had married eighty-eight beautiful women. Amat Banta's mother, King Sadon's wife from Kuala Diwa, was his 99th wife. He needs one more woman as his hundredth wife as a condition of perfecting his power. Before obtaining a hundred women, he could not have sex with a woman, and he continued to meditate in the palace which he made with magic. His $99^{\text {th }}$ wife was Putro Bunsu, the wife of King Sadon of the Kingdom of Kuala Diwa, having a son named Amat Banta. When Jugi Tapa brought his mother, Amat Banta was three days old. The Mother left a ring in the swing of her little son. Later that ring was the proof that he was her son she had left behind. Based on information from Bing Pho in Indonesian called Kepiting Uca (fiddler crab), Amat Banta looked for his mother to Blang Laka (in the current known as Bener Meriah Regency), where Jugi Tapa collected ninety-nine women, including Amat Banta's mother. With the help of Amat Banta 's mother who had obtained the secret of Jugi Tapa's magic from Jugi Tapa's mouth, Amat Banta managed to kill Jugi Tapa. Several messages can be taken from the story of Jugi Tapa, both as symbols, indexes, and icons. First, good deeds do not always get good replies. Therefore, every good work must be done sincerely so that we are not disappointed later on. Second, women should not be kept secret. Third, we cannot fight the teacher.
\end{abstract}

Keywords: Jugi Tapa Saga, Literature Code, Literacy, Transliteration

\section{Introduction}

Literature is a reflection of people's lives. Through literary works, an author reveals the problems of life that the author himself is in. Literary work receives influence from the 
community and is also able to influence society. The community often determines the value of literary works that live in an era, while the author himself is a member of society who is bound to certain social status and cannot avoid the influence he receives from the environment that raises and forms it at the same time (Luxemburg, Bal and Weststeijn, 1991).

Literature is a human creation, and creation is not merely an imitation. Literary work as a form and outcome of creative work is necessarily a medium that utilizes language to express human life. Therefore, a literary work generally contains problems that surround human life. The birth of literature is motivated by the human urge to express his existence. The disclosure of human existence is expressed verbally and in writing (Teeuw, 1995).

Traditional literature is part of a culture that grows and develops in the midst of society. Traditional literature life, especially saga, can be said to still revolve around folk literature because the literary text is still very little recorded. Oral literary texts are partly stored in the memories of parents, which are now diminished in the modern environment.

Saga is an old prose-shaped literary work that contains stories, laws, and genealogies that are fictional, religious, historical, biographical, or a combination of these qualities. The saga is read for solace, a fighting spirit, or to enliven the party (Endraswara, 2009).

Saga is a genre of oral literature that is the most numerous in Aceh, both regarding the number and extent of its contents. Until now, it is not known precisely how many Acehnese sagas has ever existed (ever been created or ever written) and that is still found today. Generally, the saga was initially created in an oral tradition, memorized by its creator and by people who were accustomed to hearing it.

That is how this tradition took place from generation to generation in Acehnese society. Efforts to write saga are usually carried out by other people who are not their creators. However, some sagas were written from the beginning of their creation by the creator himself, although later they were often copied again and carried out here and there by others. Therefore, it is not surprising that we find some authors of a saga and sometimes it is quite difficult for us to get information about who the original author of the sagas. This habit applies to the culture of oral traditions. Likewise the sagas in Acehnese society.

At this time it was scarce for Acehnese to memorize saga and also be able to convey it well to the public. Also, the younger generation in Aceh, in general, are no longer fond of the saga, a result of changing times. It can be ascertained that if the saga that ever existed in Aceh will disappear without a trace if it is not considered and reviewed. This is important as an intangible cultural heritage, which is the treasure of Indonesia's cultural wealth. This study is no less important because in the story there are various meanings that can become learning in the formation of the character and identity of future generations of Indonesia.

Therefore, the author is interested in examining the nation's cultural heritage with the title, "The Code of Literature in the Acehnese Oral Literature in Jugi Tapa Saga."

\section{Research Methodology}

\subsection{Location of the Research}

The data were collected from the respondents at Sawang subdistrict, North Aceh Regency, Aceh Province.

\subsection{Research Methodology}

The author used descriptive-qualitative methods in carrying out this research. That is, the author recorded carefully when the respondents or speakers recited the story of Jugi Tapa. For the completeness and accuracy of the data, the author not only records when the respondents 
showed or recited the Jugi Tapa saga in front of the public, but also met them specifically to reclassify the data that the previous author had recorded. The descriptive method aims to record systematically, factually, and accurately the facts of a particular area. The implementation of this method refers to the ongoing problem, and its nature describes a situation in a systematic, factual and actual way. With this method, the data obtained can be processed, classified, and analyzed to draw accurate conclusions.

\subsection{Data Collection Techniques}

The data were collected from the respondents at Sawang subdistrict, North Aceh Regency, Aceh Province. For the accuracy of data collection and information, the author collected the data with the following ways:

\section{a. Recording}

The author recorded the utterance or chant of Jugi Tapa saga from the respondents, both the primary respondent and the supporting respondents.

\section{b. Interview}

Interviews were conducted to clarify the data that had been obtained through previous recordings. It is done to obtain main data and additional data so that the results of this study are indeed valid. If there is an error or mistakes with the interview, the process and the error will be corrected.

\section{c. Writing}

After the recording process, the author will write the oral data contained in the recording cassette into written form. Jugi Tapa's literary work which previously can only be heard as a form of oral literature changes into literary works that can be read or written. Literacy here is done in local language, that is, Acehnese, using Latin script. Thus, the aesthetic value is maintained. In general, a literary work in a particular language if translated into other languages, the beauty or aesthetic will not be the same as in the original language. Therefore, for the first step recording is done in the original language, that is, the Acehnese language.

\section{d. Translating}

The object of this research is the oral literary works of the Aceh region. In order for this valuable literary work to be enjoyed on a broader scale, the author will translate it into Indonesian. Of course, the ethical value of a literary work will be slightly reduced if the literary work is translated into other languages. However, the author will try to do translation as carefully as possible so that the aesthetic value in the original work is not much reduced

Data analysis was conducted to answer research problems. In qualitative research, data analysis can begin without waiting for the data to be collected. Analysis can be done in line with the data collection stage (Chaer, 2007: 46). The research data are processed qualitatively. Data processing is carried out in several stages. It needs to be done to get complete data. The data processing and analysis stage are carried out as follows.

a) The first stage is to analyze data based on sign science theory or semiotics. This analysis aims to find out the meaning through the codes contained in Acehnese oral literature in Jugi Tapa saga.

b) The second stage is to transcribe or write Acehnese oral literature, Jugi Tapa saga, which has been recorded in written form using Latin letters. This stage is intended to obtain complete data. It is transcribed in writing from the source; it is hoped that this literary work will not disappear if the saga narrators die. Thus, this great literary work can be known and read by the next generation.

c) The third stage is to translate the story of Jugi Tapa which has been written in Latin letters into Indonesian. It is intended that this literary work is not only enjoyed by the local population, that is those who speak the Acehnese language, but can also be enjoyed by a 
wider audience, such as the people of Indonesia or anyone who masters Indonesian or Malay.

\section{Result And Discussion}

Jugi Tapa saga is oral literature that lives in the midst of the people of Aceh, especially in North Aceh and Bireuen Regencies. At present, Acehnese oral literature is threatened with extinction, including its saga. The audience is increasingly shrinking, along with the decline of the older generation. The younger generation can barely memorize saga. Even more concerned that the number of saga narrators is only one or two more people, their age is very advanced, the average age is over eighty. If they die, then at the same time Acehnese oral literature will be buried, without being known by the next generation.

Jugi Tapa saga begins with praises to Allah SWT, greetings to the Prophet Muhammad SAW. It shows that this saga was written when Islam had become an official religion in Aceh.

Next, the narrator tells the listeners, he will tell a terrific story, which he has heard. He had heard the story for a long time. Then, the narrator asks the listeners to listen carefully.

The narration began when Leube Muda was asked by his teacher, Teungku Lhok Drien, to deliver a book to a scholar named Teungku Jambo Haji in another village. The teacher advised him not to open or read the book.

Leubee Muda did not comply with the prohibition from his teacher, on the way he read the book and memorized it well. Supported by his intelligence, in a moment Leubee Muda had mastered the knowledge contained in the book. The teacher learned that he had opened and memorized the contents of the book. Teungku Lhok Drien was very angry. He never thought that the student he loved so much was not trustworthy. Even so, the love of Teungku Lhok Drien to Leube Muda has not disappeared. Over time, his feelings of anger have begun to subside. However, young Leube did not; he instead began to joke with his teacher by changing the form of the teacher with various forms to test his new magic.

Then there was a fascinating battle between the teacher and students by changing their forms in various forms, such as being a banana tree, a bucket, sand, water, and birds. Fighting takes place in water and the ground. Due to pressure, Lebee Muda fled to Blang Laka, Pintu Rime Gayo subdistrict, Bener Meriah regency, Aceh Province, and Leubee Muda changed her name to Jugi Tapa.

Up to this part, everything is a symbol. Explicitly, the narrator gives a message to listeners that we must respect the teacher. Never make fun of and fight the teacher. Don't be like Leube Muda who later became Jugi for fighting his teacher. The name Jugi in this saga connotes not good: the evil of his character does not know to thank, has no empathy for others, disobedient to the teacher.

In Blang Laka, Jugi built a palace with his spell. It was in this palace that Jugi kept beautiful women consisting of daughters and wives of kings and state officials, whom he took with the power of his spells.

Before Jugi went to look for beautiful women for the perfection of his magic, he kept his soul in a magpie in the middle of a Sibonbon tree in the middle of a swamp. The swamp contains venomous animals such as dragons, snakes, scorpions, and others. All venomous animals are made Jugi with the spell. To guard the bird, he was assigned a man named Dalem Maddi. Jugi charms Dalem Maddi, so he does not know the way to go home, can't go anywhere, and can't think well. His daily work is only fishing. He ate what he fish every day.

For the perfection of his spell and magic, Jugi Tapa must marry a hundred beautiful women. Jugi Tapa was imprisoned in his palace to see the existence of beautiful women who 
would be made his wife. He has managed to collect ninety-eight women, only two more women left. Blang Laka is quiet; there are no more people. Some were killed, some were bewitched into various objects, such as stones, wood trees, fence posts, and others. Only a woman lived there named Ni Kubayan. This old woman was assigned by Jugi Tapa to look after and entertain the women who were brought with his spell.

Every day Jugi looks for two more women to take to Blang Laka. One day he heard there was a beautiful wife of the king Sadon, named Putro Bunsu, in Kuala Diwa. This beautiful woman gave birth to a boy named Amat Banta, while her husband had gone deer hunting into the forest. The king went hunting deer to fulfill his wife's desire to crave deer meat. The king left while his wife was pregnant. Until his wife gave birth to, he had not returned.

Shortly after Putro Bunsu had just given birth, Jugi Tapa arrived at Putro Bunsu's house. He brought Putro Bunsu without any objections because the Putro had been given a spell by Jugi. Even so, Putro was very sad; he just saw his gorgeous son, he had to separate. Putro Bunsu left a ring for the baby, hoping that later his son would be a man, Putro Bunsu could recognize him with the ring. Jugi Tapa brought Putro Bunsu to his palace in Blang Laka. The days of Putro Bunsu were guarded by an old woman named Nikubayan. Nikubayan is the woman who entertained Putro Bunsu, especially by making beautiful bouquets for the Putro every day. When King Sadon returned from hunting, he could not find his queen. His wife was brought by Jugi Tapa. He knew this sad news from his wife's older brother - in Aceh, he was called Tumuda. Not waiting long, after leaving all the clothes of greatness and a sword for the son, King Sadon went with a horse to find his empress to Blang Laka at night. Jugi Palace is located there - in Aceh language called Kuta.

It is awful, Jugi knows King Sadon is heading to his place. Then, Jugi sends a spell. King Sadon and his horse were caught in a wild almond tree (Sterculia foetida) - in the Acehnese language called geulumpang — because of Jugi's spell. King Sadon with his horse became the branch of the big tree. Until there is still a branch of the tree that resembles a horse being ridden by humans. Therefore, the place was named Sawang (now Sawang subdistrict) which came from the word sawak. The word sawak in Indonesian means hooking onto; meusawak means getting stuck. That is, King Sadong was caught (meusawak) on the tree. From the word sawak (hook onto) that is the origin of the name Sawang village. Now Sawang is the name of a sub-district in North Aceh Regency.

Amat Banta lives in the Kuala Diwa palace with his aunt (makwa). His aunt was the one who cared for Amat Banta. Entering the age of five, Amat Banta is already good at speaking. Every day he plays with his peers. The game that they often play is panta. Amat Banta is very good at playing panta. His friends were always hit by Amat Banta until his friends' ankles bled. Because of this, his friends began to question Amat Banta. Among them, there were those who ordered to beat Amat Banta, and said, "Why fear to the child who has no father and mother." Amat Banta's heart was sorrowful. While crying Amat Banta went home. Amat Banta asks the truth, is it true that he does not have a father and mother. Having heard the question, he was somber and unable to stem his tears. However, his intention could still convince Amat Banta that he had a mother, while his father had died when Amat Banta was still a baby. Amat Banta believes, and his heart is no longer upset.

Days later, Amat Banta no longer played with his friends. To fill his days, Amat Banta fished in Krueng Ajo. Amat Banta is happy with his new activities. That is what he does every day. At the time Banta Amat was busy fishing, came bing pho (fiddler crab), in Indonesian called kepiting uса. As a rule, crabs have a pair of pincers. However, this crab has one small clamp. Once upon a time, in this saga, it was stated that one of the clamps of the crab was small because Amat Banta beats it with a fishing rod.

Bing Pho told Amat Banta that her mother had been taken by Jugi Tapa to Blang Laka. Hearing this information, Amat Banta was furious; then he hit the bing pho with a fishing rod 
so that the one bing pho's pincer was broken. Bing pho is very sorry. "If I knew this as a consequence, of course, I would not tell you that," said Bing Pho at Amat Banta. "O Amat, now I am challenging, one my pincer has perished. It is good what I did; yet it is horrible what you reward me, "Continued Pho.

In this section, there is an icon, that not all the good we do to others will be rewarded with kindness. Sometimes the good we do to others is repaid with evil, as experienced by Bing Pho. The consequences must be borne by all bing pho offspring until now. All bing pho have small hands, due to their ancestors were hit by Banta Amat in the past. To this day, if the crab is cornered with a human, it will raise its pincer as a sign he is asking forgiveness not to be hit again. Genetically, the fear is passed on to the child, not only physically, which makes the offspring have one small pincer.

After Amat Banta heard what Bing Pho had said, he immediately returned home with a broken heart. Arriving at the house, Amat Banta asked the truth about his father. Every day Amat Banta asks the truth of what Bing Pho said. Based on the consideration that Amat Banta was old enough and kept asking about this matter, so his Makwa told Amat Banta the truth, that what was reported by Bing Pho was true.

Not long afterward, Amat Banta asked his aunt for permission to look for the mother who had been brought by Jugi Tapa, and his father who had never returned when searching for his mother in the past. Amat Banta left riding on a flying horse - an offspring of his father's horse which had held in the past. After going through the clouds and jungles for days, Amat Banta finally saw a palace. In front of the palace sat a fat old woman with no teeth. Amat Banta approached the woman, named Ni Kubayan. Amat Banta and Ni Kubayan became familiar each other. Amat Banta can stay in Ni Kubayan's house.

Ni Kubayan was very scared if Putri Bunsu knew that there was a young man in her house. Ni was afraid that Putro would say to Jugi. If Jugi knows, he wold spell Amat Banta into wood or stone. Therefore, Ni Kubayan always hid Amat Banta on the second floor when Putro Bunsu took a bouquet of flowers every morning at the home of Ni Kubayan.

One morning, Putro Bunsu saw an exquisite bouquet of flowers, not as usual. The Putro was suspicious; maybe there was another hand that made it. Until that time she asked Ni Kubayan. However, Ni still did not admit, she did. Princess Bunsu became more suspicious when she saw a ring on Ni Kubayan's finger. The ring used by Ni Kubayan was Amat Banta's ring which she left when she was taken by Jugi Tapa. When Putro used it, the ring is very fitting because it was the ring left to his son when Jugi Tapa took her.

Putro Bunsu was increasingly suspicious that Amat Banta was hidden by Ni Kubayan in the house. Putro looked for it and found Amat Banta hidden by Ni under the large pot. After knowing who the young man was, Putro cried, her tears unbearable. None other than that, the young man was her son who had been left in the swing when he was three days old.

After that, Putro Bunsu immediately returned to Jugi Tapa's palace. With persuasion, Putro Bunsu asked where Jugi kept his soul. Without prejudice, Jugi told where Jugi kept his soul. No one could get to that place because Jugi had given magic, surrounded by a deep swamp, and full of venomous creatures. With beautiful words, Putro Bunsu kept asking how to get to that place. Because of his love for Putro Bunsu, Jugi told everything. After everything was obtained from Jugi Tapa, Putro Bunsu immediately returned to Ni Kubayan's house. Putro Bunsu handed over all the magic obtained from Jugi Tapa and told all the ways to Amat Banta. With all these, Amat Banta set out to take Jugi's life which he kept in a magpie in the sibon-bon tree, which was located on a mountain in the middle of a large brackish filled with venomous animals.

With all the supplies provided by his mother, Amat Banta went to retrieve the magpie, where Jugi Tapa kept his soul. Amat Banta had to climb a large tree to take the bird, but it was not easy. The bird was very agile, jumping from one branch to another. Amat Banta cut down 
the branches one by one. One of the branches of the tree was blown away to Samalanga. Finally, Amat Banta managed to catch a magpie, where Jugi Tapa kept his soul.

After Amat Banta can catch the bird, he immediately returns to Jugi's palace. When looking at Amat Banta with the bird on his hand, Jugi Tapa was very angry. Jugi with all tricks was trying to ask the bird from Amat Banta. Amat Banta did not give it. It made Jugi even more irritated. At that moment Amat Banta killed the bird by breaking its neck. At the same time, Jugi met his death.

In this section, there is a message that can be categorized as an index. The message is conveyed explicitly by the narrator that we do not easily trust women. Women cannot keep secrets. As experienced by Jugi, he died because of his beautiful young wife's trick. If the secret was not conveyed to his young wife Putro Bunsu, of course, he had not died.

\section{Conclusions}

After the writer examines "Acehnese Oral Literature in Jugi Tapa saga," researchers can formulate some conclusions as follows.

Jugi Tapa saga is an oral language in the form of lyrical prose that has a very high aesthetic value. Literary works expressed in Acehnese ethnic language, of course, have separate characteristics. Each literary work is very close to the language used as a tool for disclosure.

As oral literature, this literary work is hazardous to be threatened with extinction. More and more days, the number of saga narrator is getting smaller. They are generally older generation, which is currently over seventy years old. If it is not written, it is certain that the great work will disappear along with the person who remembers the story.

In the story of Jugi Tapa, more symbols are found, when compared with indexes and icons. This literary work can be classified as a legendary literary work, in which there is a story of the origin of the region or place.

This saga contains essential messages that are generally conveyed with symbols. The main message, the amount may not be the cost of the teacher's mandate, not obedient to the teacher. As a result, the sinful life will happen as shown by Jugi Tapa who is the main character in this saga. He became misguided by practicing black magic. His life is not happy and finally dies in vain. Some of the messages were explicitly conveyed as in lines 1793 to line 2008. In this section, the author immediately advised that we should not keep secrets to women. Jugi Tapa died because he gave his secret to his young wife. In this section, the author also states explicitly that if someone opposes his teacher, his final destiny ends like Jugi Tapa

This saga is more interesting for the listeners because it tells the origin of various places. It is also told the reasons for the fiddler crab which has one small pincer. Uniquely, the places where events occur (settings) are in adjacent areas that can be recognized until now, that is Kuala Diwa, Sawang, Blang Laka, Samuti, Samalanga. All of these places are the name of the village, except Sawang and Samalanga which have become the names of sub-districts and the names of their sub-district capitals. Thus, it can be estimated; the authors are from around Sawang sub-district now.

Moreover, all the locations (settings) are in Sawang subdistrict, except Blang Laka and Samalanga. Geographically, at present Sawang is in the North Aceh Regency, Blang Laka in the Bener Meriah Regency area, and Samalanga in the Bireuen Regency. It shows that the place where the event occurred is in the adjacent area.

There are several parts in the index, such as the ring left by Putro Bunsu to Amat Banta when she was picked up by Jugi Tapa. The ring was handy when Amat Banta became an adult. That ring is a strong indication that the young man was the son she had left behind when 
he was three days old in the swing. The ring is more valuable than a thousand words. There was not the slightest suspicion in Amat Banta's mother's heart that it was the flesh and blood she had left behind when he was a baby.

Icons in this saga are found in bing pho or fiddler crab. In this section, there is a profound message. Bing pho becomes an icon that good deeds do not always get the same reward, it can happen as bing pho experienced. In the past, bing pho had a pair of pincers that were the same size. Because of the good deeds it did, one of its pincer became small. Ironically, the defective organ was inherited in its generation to the end of time. Because it told Amat Banta that his mother (mother of Amat Banta) had been taken by Jugi Tapa to Blang Laka.

Bing pho not only inherits physical defects to its offspring but also bequeaths genetics. Bing pho or fiddler crab is very afraid of humans. If accidentally meets with humans, the crab will raise both pincers, like asking forgiveness not to be beaten again, and he will run away hiding in the ground. This icon is amazing. The author can look for an analogy to describe that good deeds do not always get good rewards. For example, bing pho. He does not only receive the consequences of his good deeds alone, but his descendants must bear the consequences of good deeds that were done by his ancestors in ancient times. With this icon, the author mandates that if we do something good, we must be sincere, do not expect a good reply, if we do not want to be disappointed later. If we something good, but we are rewarded with evil, it is nothing when compared to what is experienced by Bing Pho or fiddler crab.

\section{Suggestions}

Based on this study, the author has several suggestions as follows.

First, the saga of Jugi Tapa has a high aesthetic value. This saga is in the form of lyrical prose which belongs to the type of legend.

Second, oral literature of Jugi Tapa saga has very important messages as part of character education and local wisdom for the young generation as the heir of the nation.

Third, oral literature in Aceh is extinct. Therefore, it is imperative that this literary work be researched and documented so that this work can be read by future generations.

Fourth, the author expects the government to be able to save oral saga literature by providing research funds and publishing the results of research in book form. These books can be distributed to libraries in Aceh and outside Aceh.

Fifth, the author expects oral literature to be used as local content in schools as part of character education and local wisdom. It also becomes essential to save Acehnese language and literature and as good learning for the nation's generation.

Sixth, the writer expects the Acehnese to be able to make oral literature as a means of education and entertainment for their daughters in the family environment. It is very useful in characterizing children's character and also serves as a means of inheriting political wisdom.

\section{References}

[1] Endraswara, S. (2009) Metodologi Penelitian Folklor. Yogyakarta: Media Presindo.

[2] Luxemburg, J. Van, Bal, M. and Weststeijn, W. G. (1991) Pengantar Ilmu Sastra. Jakarta: Intermasa.

[3] Teeuw, A. (1995) Sastera dan Ilmu Sastera: Pengantar Teori Sastera. Kuala Lumpur: Dewa Bahasa dan Pustaka.

[4] Aliana, Zainul Arifin. At.al. 1997. Ekspresi Semiotik: Tokoh Mitos dan Legendaris dalam Tutur Sastra Nusantara di Sumatera Selatan. Jakarta: Pusat Pembinaan dan Pengembangan Bahasa. 
[5] Barthes, Roland. 1996. Unsur-Unsur Semiologi: Langua dan Parolell dalam Panuti Sudjiman dan Aart van Zoest (ed). Serba-Serbi Semiotika. Jakarta: Gramedia Pustaka Utama.

[6] Eagleton, Terry. 2006. Teori Sastra: Sebuah Pengantar Koperhensif. (Terjemahan Harfiah Widyawati). Yogyakarta: Jalasutra.

[7] Husin, S. Jaafar. 1995. Penelitian Sastra: Metodologi dan Penerapan Teori, Kuala Lumpur: Dewan Bahasa dan Pustaka.

[8] Siswanto, Wahyudi. 2008. Penganar Teori Sastra. Jakarta: Grasindo.

[9] Sudjiman, Panuti dan Aart van Zoest (ed). 1996. Seba-Serbi Semiotika. Jakarta: Gramedia Pustaka Uama

[10] Muradi, Supardy (ed). 1990. Kesusastraan daripada Perspektif Semiotika. Kuala Lumpur: Dewan Bahasa dan Pustaka.

[11] Sebeok, Thomas A., 1994. An Introduction to Semiotic. London: Pinter Publis

a. $\quad$ 1994. Indonesia antara Kelisanan dan Keberaksaraaan. Jakarta: Pustaka

[12] Jaya.

[13] Trabaut, Jurgen. 1996. Dasar-Dasar Semiotik (Elemente der Semiotic). Terjemahan Sally Pattinasrany). Jakarta: Pusat Pembinaan dan Pengembangan Bahasa.

[14] Winner, Irene Portis dan Jean Umiker Sebeok (ed). 1979. Semiotics of Culture. New York: Mouton Publishers.

[15] Zoest, Aart van. 1996. Interpretasi dan Semiotikall, dalam Panuti Sudjiman (ed). Serba-Serbi Semiotika. Jakarta: Gramedia Pustaka Utama.

i. $\quad$ 1991. Fiksi dan Non-fiksi dalam Kajian Semiotika. (terjemahan Manoekmi Sardjoe). Jakarta: Intermasa. 
